\title{
Penggunaan Umbi Gembili sebagai Prebiotik Alami terhadap Persentase Karkas dan Lemak Abdominal Broiler
}

\section{Utilization Of Gembili Tuber as A Natural Prebiotic on the Percentage Carcass and Abdominal Fat Of Broiler}

\author{
N. Fajrih ${ }^{1 *}$ dan M. Khoirudin ${ }^{2}$ \\ ${ }^{1,2}$ Fakultas Pertanian Perikanan dan Peternakan \\ Universitas Nahdlatul Ulama Lampung \\ Corresponding author : nunu.nurul91@gmail.com
}

Sejarah artikel : Menerima : 08 Oktober 2019 Revisi : 22 Oktober 2019 Diterima : 23 Desember 2019 Online : 03 Januari 2020

\begin{abstract}
ABSTRAK
Tujuan penelitian adalah untuk mengkaji pengaruh pemberian prebiotik alami dari tepung umbi gembili terhadap persentase lemak abdominal, persen berat karkas dan potongan komersil karkas pada broiler. Penelitian menggunakan rancangan acak lengkap (RAL) dengan 4 perlakuan dan 5 ulangan (masing-masing 10 ekor). Perlakuan meliputi : P0 $=$ Ransum tanpa tepung umbi gembili, $\mathrm{P} 1=$ Ransum $+0,5 \%$ tepung umbi gembili, $\mathrm{P} 2=$ Ransum $+1,0 \%$ tepung umbi gembili, $P 3=$ Ransum $+1,5 \%$ tepung umbi gembili. Ransum perlakuan diberikan selama 4 minggu pemeliharaan yaitu dari umur 8 hari sampai umur 35 hari. Ayam dipelihara selama 4 minggu, selama 1 minggu pertama ayam dipelihara pada kandang litter. Umur 1 minggu, ayam ditimbang untuk memperoleh bobot badan seragam kemudian dipindahkan ke kandang baterai sesuai dengan perlakuan dan ulangan. Data dianalisis varian dan dilanjutkan dengan uji Duncan pada probabilitas $5 \%$. Hasil penelitian menunjukkan bahwa pemberian inulin umbi gembili menunjukkan pengaruh yang nyata $(\mathrm{P}<0,05)$ terhadap persentase lemak abdominal namun tidak terhadap persentase berat dan potongan komersial karkas pada broiler. Kesimpulan penelitian bahwa level tertinggi inulin yaitu sebesar 1,5\% mampu memperbaiki persentase karkas dan persentasi potongan karkas, disamping itu juga mampu menurunkan persentase lemak abdomen pada broiler.
\end{abstract}

Kata Kunci : Broiler, umbi gembili, karkas, lemak abdominal.

\section{ABSTRACT}

The research was aimed to examine the effect of giving gembili tuber as a natural prebiotic on percentage of carcass, carcass commercial cut and abdominal fat content of broiler. The research was assigned in a completely randomized design with 4 treatments and 5 replications (10 birds each). The treatments applied were P0 : ration without gembili tuber powder, $\mathrm{P} 1$ : ration $+0,5 \%$ gembili tuber powder, $\mathrm{P} 2$ : ration $+1,0 \%$ gembili tuber powder , P3 : ration $+1,5 \%$ gembili tuber powder. Treatment of ration was given for 4 weeks of maintenance from 8 days to 35 days. . Broiler has been maintened for 4 weeks, during the first week broilers are maintain in a litter cage. Age 1 week, broiler are weighed to obtain uniform body weight. The data were statistically analyzed according to ANOVA and continued to Duncan test at the 
level of $5 \%$ probability. The results showed that feeding inulin of gembili tuber were significantly $(\mathrm{P}<0.05)$ on abdominal fat content of broiler, but not to percentage of carcass and commercial cut carcass. In conclusion the higher level of feeding inulin of gembili tuber up to the highest level namely $1,5 \%$, were able to improve the percentage of carcass and carcass commercial cut, besides that it is also able to reduce the percentage of abdominal fat in broiler.

Keywords : Broiler, Gembili Tuber, Carcass, abdominal fat.

\section{PENDAHULUAN}

Broiler merupakan ayam ras pedaging unggulan yang berasal dari hasil persilangan bangsa ayam pilihan dengan kemampuan produksi yang lebih tinggi salah satunya sebagai penghasil daging yang lebih baik dan mampu dipanen dalam waktu yang relatif singkat (Haroen, 2003). Disamping itu menurut Astuti et al., (2015) bahwa ayam broiler memiliki beberapa keunggulan antara lain pertumbuhan yang lebih cepat, memiliki cita rasa daging yang empuk dan khas, selain itu lebih efisien memanfaatkan pakan menjadi daging serta harga yang lebih terjangkau. Broiler hingga saat ini masih menjadi prioritas utama dalam memenuhi kebutuhan pangan hewani terbukti dengan data Dirjen Peternakan dan Keswan pada tahun 2014, bahwa kebutuhan daging nasional disumbang oleh ternak unggas sebesar $66,27 \%$ dan berdasarkan jumlah tersebut dilaporkan bahwa broiler menyumbang sebesar $77,17 \%$. Berdasarkan hal tersebut, maka berbagai upaya yang dilakukan peternak untuk meningkatkan performa produksi broiler yaitu dengan perbaikan manajemen pemeliharaan dan juga pakan termasuk penambahan feed additive.

Feed additive atau pakan tambahan memiliki tujuan untuk memperbaiki dan memacu pertumbuhan serta mampu meningkatkan produksi daging yang lebih baik. Pertumbuhan yang lebih cepat pada broiler akan diikuti perlemakan yang juga lebih cepat sehingga penimbunan lemak juga akan meningkat seiring dengan bertambahnya umur broiler. Maka dari itu, penambahan feed additive ke dalam pakan perlu dilakukan salah satunya agar dapat mengurangi timbunan lemak dalam tubuh broiler. Pakan tambahan atau Feed additive yang biasanya digunakan oleh peternak adalah dengan pemberian antibiotik, tetapi seiring berjalannya waktu maka penggunaan antibiotik sudah tidak diperbolehkan lagi untuk digunakan. Maka dari itu, perlu dicari alternatif pengganti antibiotik yaitu dengan pemberian prebiotik alami. Prebiotik merupakan zat gizi yang tidak bisa dicerna enzim pencernaan, tetapi dapat difermentasi oleh mikrobia dalam saluran pencernaan menjadi sumber energi sehingga dapat memberikan efek positif terhadap peningkatan kesehatan tubuh. Prebiotik alami dapat diperoleh dari tanaman gembili karena pada umbinya mengandung inulin yang dapat berfungsi sebagai prebiotik alami untuk menunjang pertumbuhan dan produktifitas ternak.

Gembili (Dioscorea esculenta) merupakan tumbuhan yang dapat tumbuh pada berbagai wilayah di Indonesia. Tanaman gembili tumbuh secara liar disekitar pekarangan masyarakat dan juga dapat ditemui di hutan-hutan. Umbi dari gembil pada umumnya dimanfaatkan masyarakat sebagai alternatif pangan sumber karbohidrat. Namun, hingga saat ini masih sangat terbatas pemanfaatannya. Gembili adalah jenis tanaman yang berbuah dibawah tanah yang jenis umbinya tumbuh merambat dengan tinggi mencapai 3-5 $\mathrm{m}$ dengan batang yang berduri dan daun yang berwarna hijau. Tanaman gembili mengandung karbohidrat sebesar 
$31,3 \%$, protein $1,1 \%$, serat $1 \%$, lemak $0,2 \%$, Abu, $14 \%$ dan Inulin sebesar 14,62\% (Prabowo et al., 2014).

Inulin merupakan sumber prebiotik alami yang merupakan polimer dari unitunit fruktosa memiliki gugus terminal yaitu glukosa. Fruktosa rantai linier dari inulin mempunyai struktur yaitu GFn dengan G yaitu unit glukosa, $F$ adalah unit fruktosa dan $\mathrm{n}$ adalah jumlah unit fruktosa hampir seluruhnya berikatan satu sama lain. Inulin termasuk dapat larut dalam air, tetapi tidak mampu dicerna oleh enzim sistem pencernaan melainkan dapat difermentasi oleh mikrobia atau bakteri yang ada dalam usus besar sehingga mampu memberikan pengaruh positif terhadap kesehatan saluran pencernaan dan berpengaruh terhadap perlemakan dan karkas broiler. Hal tersebut sebagaimana pendapat Winarti (2010) bahwa sebagai serat makanan, inulin memiliki sifat dapat larut dan sangat bermanfaat bagi kesehatan tubuh dan saluran pencernaan. Penelitian dengan penambahan feed additive yaitu dengan pemberian prebiotik alami yang bersumber dari umbi gembili perlu dilakukan, harapannya perlakuan penambahan umbi gembili ke dalam pakan broiler mampu memberikan pengaruh positif terhadap kesehatan tubuh dan berpengaruh terhadap penurunan lemak abdominal dan peningkatan berat karkas broiler. Berdasarkan hal tersebut sehingga penelitian bertujuan untuk mengetahui persentase berat lemak abdominal dan juga berat karkas broiler yang diberi perlakuan pakan dengan tambahan umbi gembili sebagai prebiotik alami.

Fajrih, Nurul dan Khoiruddin, M. / Jurnal Ternak - Volume 11 (Junis

\section{MATERI DAN METODE Waktu dan Tempat}

Penelitian dilaksanakan pada bulan Juni hingga Agustus 2019 di kandang percobaan Fakultas Pertanian, Perikanan dan Peternakan Universitas Nahdlatul Ulama Lampung.

\section{Materi Penelitian}

Penelitian menggunakan broiler unsex strain MB 202, umur 1 hari (day old chick / DOC) sebanyak 200 ekor. Ransum terdiri dari Jagung Giling, bungkil kedelai, tepung ikan, bekatul, minyak nabati, mineral, dicalsium posfat dan vitamin mix non antibiotik. Tepung umbi gembili yang digunakan adalah produk buatan sendiri yang merupakan modifikasi dari metode Azhar (2009). Ransum penelitian disusun berdasarkan kandungan energi metabolis $3.000 \mathrm{kkal} / \mathrm{kg}$ dan protein $21 \%$. Ransum perlakuan diberikan selama 4 minggu pemeliharaan yaitu dari umur 7 hingga umur 35 hari.

Ayam dipelihara selama 5 minggu, selama 1 minggu pertama ayam dipelihara pada kandang litter. Umur 1 minggu, ayam ditimbang untuk memperoleh bobot badan seragam kemudian dipindahkan ke kandang koloni dengan ukuran $1,5 \times 1$ meter sesuai dengan perlakuan dan ulangan. Ransum dan air minum diberikan secara ad libitum. Minggu pertama ayam diberi ransum komersil dan dilanjutkan menggunakan ransum basal yang formulasinya disajikan pada tabel 1. Umur 4 hari, ayam diberi vaksin Newcastle Disease (ND) dan vaksin Gumboro pada umur 13 hari untuk mencegah terserang penyakit. Pemberian pakan komersil dilakukan pada umur 1 sampai 7 hari dan pakan perlakuan diberikan pada umur 7 sampai 35 hari. Pemberian tepung umbi gembili dilakukan dengan cara tepung dicampurkan ke dalam ransum pada pagi hari hingga habis dikonsumsi ayam kemudian selanjutnya diberikan ransum tanpa tepung gembili disertai pemberian air minum secara ad libitum. 
Rancangan percobaan.

Rancangan percobaan yang digunakan pada penelitian ini adalah dengan metode RAL (Rancangan Acak Lengkap), 4 perlakuan 5 kali ulangan dengan menggunakan 10 ekor ayam pada setiap ulangan. Sehingga jumlah ayam yang dipelihara secara keseluruhan adalah sebanyak 200 ekor. Adapun perlakuan penelitian yaitu :

$\mathrm{PO}=$ Ransum tanpa tepung umbi gembili

$\mathrm{P} 1=$ Ransum $+0,5 \%$ tepung umbi gembili

$\mathrm{P} 2=$ Ransum $+1,0 \%$ tepung umbi gembili

P3 $=$ Ransum $+1,5 \%$ tepung umbi gembil

Tabel 1 . Komposisi kandungan nutrien ransum basal

\begin{tabular}{lclc}
\hline \multicolumn{1}{c}{ Bahan Pakan } & Jumlah $(\mathrm{kg})$ & \multicolumn{2}{c}{ Kandungan Nutrisi } \\
\hline Jagung Giling & 56,5 & PK (\%) & 21,17 \\
Bekatul & 6,0 & EM (Kkal.kg) & 3092,9 \\
Bungkil Kedelai & 18,0 & SK (\%) & 2,72 \\
Tepung Ikan & 15,0 & LK (\%) & 7,82 \\
Minyak Nabati & 3,0 & Ca (\%) & 1,21 \\
Dicalsium pospat & 0,5 & P (\%) & 1,05 \\
Mineral dan vitamin mix non & 1,0 & & \\
antibiotic & 100,0 & & \\
\hline \multicolumn{2}{c}{ Jumlah } & & \\
\hline
\end{tabular}

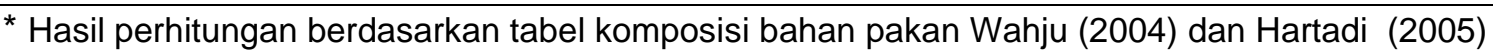

\section{Parameter Penelitian}

Parameter penelitian yang diamati yaitu persentase lemak abdominal, berat karkas dan persentase potongan komersil karkas (sayap,dada dan paha) sebagaimana diuraikan berikut :

\section{Persentase lemak abdominal (\%)}

Berat lemak abdominal diukur dengan cara lemak yang diperoleh dari sekeliling gizzard dan lapisan lemak yang menempel pada rongga perut, dikumpulkan kemudian ditimbang beratnya. Persentasenya dapat dihitung menggunakan rumus berikut :

Persentase Lemak Abdominal (\%) = berat lemak abdominal (gr) x 100\% berat hidup (\%)

2. Persentase karkas (\%)

Karkas merupakan hasil penyembelihan ayam setelah dikeluarkan bulu, isi rongga dalam perut, kepala dan kaki, kemudian persentasenya dihitung menggunakan rumus berikut :

Persentase berat karkas (\%) = berat karkas (gr) $\times 100 \%$ berat hidup (\%)

\section{Analisis Data}

Data dianalisis ragam (ANOVA) dengan uji $\mathrm{F}$ pada taraf $5 \%$. Apabila terdapat pengaruh yang nyata, dilanjutkan dengan uji Duncan (Steel dan Torrie, 1991). 
HASIL DAN PEMBAHASAN

Persentase Lemak Abdominal dan Karkas

Rerata persentase lemak abdominal dan karkas akibat pemberian tepung umbi gembili disajikan pada Tabel 2. Hasil analisis ragam menunjukkan bahwa pemberian sumber inulin dari umbi gembili dalam bentuk tepung mempunyai pengaruh nyata $(P<0,05) \quad$ terhadap persentase lemak abdominal, tetapi tidak tehadap persentase karkas.

Tabel 2. Persentase Lemak Abdominal dan Karkas Broiler yang Mendapat Perlakuan Tepung Umbi Gembili

\begin{tabular}{ccc} 
Perlakuan & Persentase Lemak Abdominal & Persentase Karkas \\
\hline P0 & $1,98 \pm 0,20^{\mathrm{a}}$ & $63,72 \pm 8,81$ \\
P1 & $1,65 \pm 0,17^{\mathrm{b}}$ & $68,69 \pm 10,0$ \\
P2 & $1,73 \pm 0,13^{\mathrm{b}}$ & $67,64 \pm 11,4$ \\
P3 & $1,58 \pm 0.10^{\mathrm{b}}$ & $68,44 \pm 7,10$ \\
\hline
\end{tabular}

Superskrip yang berbeda pada kolom yang sama menunjukkan berbeda nyata $P<0,05$. Keterangan: $\mathrm{PO}=$ Ransum tanpa tepung umbi gembili, $\mathrm{P} 1=$ Ransum $+0,5 \%$ tepung umbi gembili, $\mathrm{P} 2=$ Ransum $+1,0 \%$ tepung umbi gembili, $\mathrm{P} 3=$ Ransum $+1,5 \%$ tepung umbi gembili.

Perlakuan dengan penambahan tepung umbi gembili 1,5\% (T3), menghasilkan persentase lemak abdominal yang nyata lebih rendah dibanding perlakuan kontrol $\mathrm{P} 0$, namun, antara perlakuan $\mathrm{P} 1, \mathrm{P} 2$ dan P3 tidak berbeda. Sementara persentase karkas menunjukkan tidak berpengaruh nyata, namun secara numerik perlakuan dengan pemberian tepung umbi gembili cenderung lebih tinggi dibandingkan kontrol tanpa penambahan tepung umbi gembili (Tabel 2).

Bobot hidup seekor ayam pada saat panen erat kaitannya dengan persentase karkas yang dihasilkan. Disamping itu, faktor pemberian ransum sangat mempengaruhi pembentukan karkas (Setiadi dkk, 2011). Berdasarkan hasil penelitian ini diperoleh persentase karkas yaitu berkisar antara $63,72 \%$ hingga $68,69 \%$ dengan rataan terendah pada perlakuan $\mathrm{PO}$ dan tertinggi pada perlakuan P3 . Hal tersebut didukung oleh pendapat North dan Bell (1992) bahwa kisaran persentase berat karkas pada broiler yaitu bervariasi antara $65-75 \%$ dari berat badan, sehingga menunjukkan bahwa jika semakin tinggi berat badan ayam yang dipotong maka akan semakin tinggi juga karkas yang dihasilkan. Sejalan dengan hasil penelitian Daud dkk (2007) bahwa persentase berat karkas broiler setelah pemotongan yaitu berkisar antara 65,35\% hingga $66,56 \%$. Sedangkan menurut penelitian Supriyatno dan Indaraji (2007) memperoleh rataan persentase berat karkas broiler usia 5 minggu yakni sekitar $59-63 \%$ dari bobot hidup. Disamping itu penelitian Sumarni (2015) memperoleh rataan persentase berat karkas sekitar 69,76 hingga $73,39 \%$.

Pemberian tepung umbi gembili pada penelitian ini menunjukkan bahwa penggunaan tepung umbi gembili hingga level tertinggi yaitu 1,5 mampu memperbaiki persentase karkas broiler dibanding dengan perlakuan kontrol, hal tersebut disebabkan karena keberadaan kandungan inulin sebagai prebiotik alami yang terdapat dalam tepung gembili yang ditambahkan ke dalam pakan. Sehingga prebiotik inulin tersebut dapat merangsang 
pertumbuhan dan jumlah BAL dalam saluran pencernaan yang mengakibatkan penyerapan makanan menjadi lebih efisien dan berefek pada pertambahan berat badan yang tentu saja akan mempengaruhi persentase karkas. Hal ini sejalan dengan penelitian Fajrih et al (2014) dan Fajrih et al (2019) sebelumnya bahwa penambahan inulin asal umbi dahlia maupun asal umbi gembili mampu memperbaiki performa petumbuhan ayam persilangan dan ikan Nila. Selanjutnya didukung oleh penelitian Fanani dkk. (2014) yang juga memperoleh hasil bahwa dengan penggunaan inulin umbi bunga dahlia yang ditambahkan ke dalam pakan ternyata dapat mempengaruhi pertambahan berat badan (PBB) pada ayam kampung super.

Perlakuan dengan pemberian tepung gembili yang tertinggi, mampu menyediakan bahan serat yang lebih banyak untuk difermentasi mikrobia saluran pencernaan sehingga dapat menghasilkan SCFA yang tinggi khususnya asetat, selain propionat. Hasil penelitian Fanani (2014) menunjukkan bahwa SCFA khususnya asetat meningkat dari $14,66 \mathrm{mMol} / \mathrm{l}$ pada T0 menjadi 24,38 $\mathrm{mMol} / / \mathrm{p}$ ada T6, juga menyebabkan penurunan $\mathrm{pH}$ saluran pencernaan sebesar 6,10 pada T0 dan 5,45 pada T6 (Krismiyanto, 2015). Komponen kedua metabolit tersebut mampu menghambat pertumbuhan bakteri patogen dan sebaliknya meningkatkan jumlah BAL. Mekanisme kerja prebiotik inulin terhadap persentase berat karkas menurut Herminiati dkk (2015), dan Widodo dkk (2015) yaitu dengan cara mikroba di dalam saluran pencernaan yang mampu memfermentasikan inulin menjadi asam laktat dan short chain fatty acids (SCFA) yang mengakibatkan penurunan $\mathrm{pH}$ usus sehingga menjadi lebih asam. Dengan adanya kondisi tersebut maka bakteri non patogen dalam usus menjadi meningkat, sehingga akan terjadi proses eliminasi bakteri patogen yang menempel pada permukaan vili-vili usus. Proses eliminasi bakteri patogen akan membuat permukaan vili-vili usus menajdi lebih luas, sehingga penyerapan makanan pun menjadi lebih efisien dan dapat mempengaruhi performa petumbuhan yang kaitannya dengan persentase berat karkas yang lebih baik.

Persentase Lemak Abdominal pada perlakuan dengan pemberian tepung umbi gembili nyata menurunkan kadar lemak abdominal pada broiler dibandingkan dengan kontrol, meski antar pelakuan $\mathrm{P} 1$ P2 dan P3 tidak berbeda (Tabel 2). Berdasarkan hasil penelitian ini diperoleh rataan persentase bobot lemak abdominal yang masih termasuk dalam kisaran normal yaitu 1,58 sampai $1,98 \%$ dengan persentase terendah yaitu pada perlakuan P3 dan persentase tertinggi pada perlakuan P0. Hal ini sesuai dengan pendapat Salam (2013) bahwa persentase lemak abdominal karkas broiler berkisar antara $0,73 \%$ sampai $3,78 \%$. Rendahnya persentase lemak abdominal yang diperoleh pada penelitian ini menunjukkan bahwa kondisi perlemakan ayam broiler cenderung lebih baik. Kualitas karkas dipengaruhi oleh hasil ikutan lemak abdominal, maka dari itu semakin kecil persentase lemak abdominal yang dihasilkan maka semakin baik pula karkas yang dihasilkan. Hal ini sejalan dengan pendapat Yuniastuti (2002) bahwa jumlah lemak abdominal pada broiler menentukan tinggi dan rendahnya kualitas karkas yang dihasilkan.

Penurunan persentase lemak abdominal yang diperoleh pada perlakuan pemberian tepung umbi gembili, ada kemungkinan disebabkan oleh pengaruh serat kasar yang terdapat dalam tepung umbi gembili. Kandungan serat kasar yang tinggi tersebut berpengaruh terhadap jumlah lemak abdominal pada broiler yang dihasilkan. Kandungan serat kasar didalam pakan yang dikonsumsi maka akan 
mengikat asam empedu setelah sampai dalam saluran pencernaan. Kondisi tersebut menyebabkan fungsi empedu dalam membantu penyerapan lemak menjadi terhambat. Kemudian selanjutnya asam empedu yang sudah terikat dengan serat kasar akan dikeluarkan tubuh berupa kotoran atau feses sehingga berdampak pada penurunan deposisi lemak abdominal (Poedjadi, 2005). Hal tersebut didukung oleh pendapat Sutardi (1992) bahwa serat kasar dapat menurunkan penyerapan lemak hingga deposisi lemak dapat ditekan dalam tubuh ayam.

\section{Persentase Potongan Komersil Karkas (Dada, Paha dan Sayap)}

Tabel 3. Persentase Potongan Komersil Karkas (Dada,Paha dan Sayap) Broiler yang Mendapat Perlakuan Tepung Umbi Gembili.

\begin{tabular}{cccc}
\hline Perlakuan & Dada $(\%)$ & Paha(\%) & Sayap(\%) \\
\hline P0 & $27,83 \pm 1,43$ & $23,95 \pm 1,57$ & $10,01 \pm 1,82$ \\
P1 & $29,10 \pm 3,20$ & $24,69 \pm 1,91$ & $10,20 \pm 1,36$ \\
P2 & $28,11 \pm 2,33$ & $24,52 \pm 2,12$ & $10,14 \pm 0,83$ \\
P3 & $29,70 \pm 1,30$ & $25,45 \pm 1,79$ & $10,49 \pm 0,79$ \\
\hline
\end{tabular}

Superskrip yang berbeda pada kolom yang sama menunjukkan berbeda nyata $P<0,05$. Keterangan: $\mathrm{P0}=$ Ransum tanpa tepung umbi gembili, $\mathrm{P} 1=$ Ransum $+0,5 \%$ tepung umbi gembili, P2 = Ransum + 1,0\% tepung umbi gembili, P3 = Ransum $+1,5 \%$ tepung umbi gembili.

Berdasarkan hasil analisis ragam menunjukkan bahwa persentase potongan komersil karkas baik dada, paha maupun sayap menunjukkan tidak berpengaruh nyata $(P<0,05)$ akibat pemberian tepung umbi gembili, namun secara numerik menunjukkan nilai yang cenderung lebih tinggi pada perlakuan dengan penambahan tepung umbi gembili. Rataan persentase potongan dada yang diperoleh dalam penelitian yaitu berkisar antara $27,83 \%$ sampai $29,70 \%$, persentase paha berkisar antara $23,95 \%$ hingga $25,45 \%$ dan persentase sayap yaitu sekitar 10,01\% hingga $10,49 \%$. Tinggi nya persentasi potongan karkas komersil secara numerik mungkin disebabkan adanya kandungan inulin yang cukup tinggi dalam ransum perlakuan. Prebiotik inulin dapat dimanfaatkan oleh BAL dengan merangsang pertumbuhannya didalam usus sehingga membuat penyerapan nutrient lebih maksimal dan efisien. Dengan begitu maka akan mempengaruhi performa perumbuhan menjadi meningkat dan secara langsung juga berdampak pada persentase karkas yang dihasilkan.

Bobot potongan komersil karkas baik dada, paha maupun sayap dipengaruhi oleh tingginya persentase karkas yang diperoleh. Hal ini didukung oleh pendapat Hadiwiyoto (1992) bahwa tingginya persentase karkas yang dihasilkan maka akan menghasilkan bobot potongan komersil dada yang juga tinggi. Sedangkan persentase potongan komersil sayap yang diperoleh lebih kecil diperoleh dibandingkan persentase berat paha dan dada. Hal tersebut mungkin terjadi karena persentase tulang pada sayap tinggi. Sebagaimana pernyataan Muryanto dkk (2002) bahwa besarnya persentase tulang mempengaruhi penurunan deposit daging pada bagian-bagian karkas. Sejalan pula dengan penelitian Sari, dkk (2014) bahwa persentase daging dada berkisar sekitar 78,66 hingga $83,24 \%$ dengan persentase tulang yang berkisar antara 14,19 hingga 
17,25\%,, sementara pada persentrase daging paha sebesar 77,24 hingga $82,07 \%$ dan persentase tulang sebesar 14,69 hingga 19,81\%,. Adapun persentase daging sayap yaitu berkisar antara 62,67 sampai $70,96 \%$ dan persentase tulangnya sebesar 24,15 sampai $31,94 \%$.

\section{KESIMPULAN}

Pemberian tepung umbi gembili sebagai sumber prebiotik alami hingga level tertinggi yaitu $1,5 \%$, mampu memperbaiki persentase berat karkas sekaligus persentasi potongan komersil karkas (dada, paha dan sayap). Disamping itu juga mampu menurunkan persentase lemak abdominal pada broiler.

\section{UCAPAN TERIMAKASIH}

Ucapan terima kasih disampaikan kepada Direktorat Riset dan Pengabdian Kepada Masyarakat (DRPM) Ristekdikti yang telah mendanai kegiatan penelitian ini melalui Program Hibah Penelitian dengan Skema Penelitian Dosen Pemula (PDP) tahun anggaran 2019 dengan SK nomor 806/SP2H/LT/MONO/L2/2019.

\section{DAFTAR PUSTAKA}

Astuti, F.K., W. Busono dan O. Sjofjan. 2015. Pengaruh penambahan probiotik cair dalam pakan terhadap penampilan produksi pada ayam pedaging. J-PAL. 6(2) : 99-104.

Azhar, M. 2009. Inulin sebagai prebiotik. J. Sainstek. $12: 23-26$.

Daud, M., W. G. Piliang dan P. Kompiang. 2007. Persentase dan kualitas karkas ayam pedaging yang diberi probiotik dan prebiotik dalam ransum. JITV, 12 (3): 167-174.
Fajrih, N., N. Suthama, and V. D. Yunianto. 2014. Body resistance and productive performances of crossbred local chicken fed inulin of dahlia tubers. Media Peternakan. 37 (2) : 108-114.

Fajrih, N., M. Khoiruddin dan A. F. Fanani. 2019. Studi Penerimaan Konsumen Terhadap Fillet Daging Ikan Nila Gift (Oreochromis Niloticus). Agromedia. Vol 37 (1) : 66-71.

Fanani. A. F.. Suthama. N and Sukamto. B. 2014. Retensi Nitrogen dan Konversi Pakan Ayam Lokal Persilangan yang diberi Ekstrak Umbi Dahlia (Dahlia variabilis) sebagai sumber inulin. J. Sains Peternakan 12 (2) : 69-75

Hadiwiyoto, S. 1992. Kimia dan Teknologi Daging Unggas. Pusat Antar Universitas Pangan dan Gizi. Universitas Gajah Mada.Yogyakarta.

Herminiati, A, Rimbawan., B. Setiawan., D. A. Astuti dan L. Z. Udin. 2015. Karakteristik yoghurt kering yang diperkaya difructose anhydride III dari umbi dahlia sebagai minuman fungsional. AGRITECH, 35 (2); 135145.

Haroen, U. 2003. Respon Ayam Broiler yang Diberi Tepung Daun Sengon (Albizzia falcataria) dalam Ransum terhadap Pertumbuhan dan Hasil Karkas. J. IImiah IImu-ilmu Peternakan. 6 (1): 34-41.

Hartadi, H. 2005. Tabel Komposisi Pakan Untuk Indonesia. Gajahmada University Press. Yogyakarta

Krismiyanto L, Suthama. N dan Hanny I. W. 2015. Keberadaan bakteri dan 
perkembangan caecum akibat penambahan inulin dari umbi Dahlia (Dahlia variabilis) pada ayam kampung persilangan periode starterJurnal-Jurnal IImu Peternakan. 24 (3) : 54 -60.

Muryanto, P.S. Hardjosworo, R. Herman, H dan H. Setijanto. 2002. Evaluasi Karkas Hasil Persilangan Antara Ayam Kampung Jantan dengan Ayam Ras Petelur. Animal Production. 4( 2) : 71-76.

Poendjiadi A. 2005. Dasar-dasar biokimia. UI Press. Jakarta.

Prabowo, A.Y., Teti Estiasih, dan Indria Purwatiningrum. 2014. Umbi Gembili (Dioscorea esculenta L.) Sebagai Bahan Pangan Mengandung Senyawa Bioaktif : Kajian Pustaka. Jurnal Pangan dan Agroindustri, 2 ; (3) : 129-135.

Salam, S., A. Fatahilah., D. Sunarti dan Isroli. 2013. Bobot karkas dan lemak abdominal broiler yang diberi tepung jintan hitam (Nigella sativa) dalam ransum selama musim panas. Jurnal Sains Peternakan, 11 (2): 84-89.

Sari, M. L., F. N. L. Lubis dan L. D. Jaya. 2014. Pengaruh Pemberian Asap Cair Melalui Air Minum Terhadap Kualitas Karkas Ayam Broiler. Agripet 1 (14), 71-75.

Suprayitno dan M. Indradji.2007. Efektivitas Pemberian EkstrakTemulawak (Curcumae xanthoriza) dan Kunyit (Curcumae domestica) dan Sebagai Immunostimulator Flu Burung pada Ayam Niaga Pedaging. J. Animal Production.9: 178-183.
Sumarni. 2015. Pengaruh kuantitas ransum terhadap persentase karkas, giblet dan lemak abdominal ayam broiler. Skripsi. Fakultas Peternakan. Universitas Halu Oleo.Kendari.

Sutardi. 1992. Pengawetan Pangan: Pendinginan dan Pengeringan. PAU Pangan dan Gizi. Universitas Gadjah Mada, Yogyakarta.

Setiadi, D., N. Khaira dan T. Syahrio. 2011. Perbandingan bobot hidup, karkas, giblet, dan lemak abdominal ayam jantan tipe medium dengan strain berbeda yang diberi ransum komersial broiler. Skripsi. Jurusan Peternakan. Fakultas Pertanian. Universitas Lampung. Lampung.

Steel, R. G. D. dan J. H. Torrie. 1991. Prinsip dan Prosedur Statistika. Diterjemahkan oleh Bambang Sumantri. PT. Gramedia Pustaka Utama. Jakarta

Wahyu. 2004. Bahan Pakan Unggas Non Konvensional. Fakultas Peternakan-Perikanan Universitas Muhammadiyah Malang

Widodo, T. S., B. Sulistiyanto dan C. S. Utama. 2015. Jumlah bakteri asam laktat (bal) dalam digesta usus halus dan sekum ayam broiler yang diberi pakan ceceran pabrik pakan yang difermentasi. Fakultas Peternakan dan Pertanian Universitas Diponegoro Semarang. AGRIPET, 15 (2) : 98-103.

Winarti, S., Harmayani, E. and Nurismanto, $\mathrm{R}$. (2011).Karakteristik dan profil inulin beberapa jenis uwi(Dioscorea app.). Agritech 31(4): 378-383. 
Yuniastuti, A., 2002. Efek pakan berserat pada ransum ayam terhadap kadar lemak dan kolesterol daging broiler. JITV, 9 (3) : 175 - 183. 